\title{
Economic Evaluation of Some Projects Funded by NGOs and Their Role in Human Development in Fayoum Governorate, Egypt
}

\author{
Enas El Sayed Sadek, Osama Metwaly Mohamed and \\ Ghada Abd El Samee Rabee Mansour Ghedan*
}

Department of Agricultural Economics, Fayoum University, Egypt

*Corresponding author

\begin{tabular}{|l|}
\hline Key w o r d s \\
Human \\
$\begin{array}{l}\text { Development, } \\
\text { economic projects, } \\
\text { the indicators }\end{array}$ \\
\hline Article Info \\
\hline $\begin{array}{l}\text { Accepted: } \\
\text { 20 May } 2018 \\
\text { Available Online: } \\
\text { 10 June } 2018\end{array}$ \\
\hline
\end{tabular}

\section{A B S T R A C T}

The importance of the economic projects and the development of the society is evident, as Egypt has great economic potentials in the fields of civil work, with the aim of transforming the economic and social structure in accordance with the scientific analysis of natural and human resources. so The research aims to study and analyze the relevant economic and social variables And to achieve the following objectives; Analysis of the most important indicators of human development in Fayoum Governorate, study the potentials and determinants of activating the developmental role of NGOs in Fayoum Governorate, evaluation of some development projects and services provided by NGOs, and their impact on achieving higher levels of human development in Fayoum Governorate. The results of the general human development index and indicators in Fayoum governorate showed that the general directory of the governorate was about 0.584 , which means that Fayoum governorate is in the low level of development which is within the level of 0.550-0.599 according to the global map of the development index Humanity. The results of the indicators of economic analysis of the projects of economic development according to the net yield index in the Egyptian pound, where the project was followed by 1850 , the dairy industry by 900 , the clothing and detailing project 1200 , the vegetable and fruit project 1250, Agricultural seedling projects (833), raising and trading poultry feed (670), shops and grocery (1100) compost project (700).

\section{Introduction}

The concept of human development is a process of planned change in order to comprehensively improve the quality of people's lives in all its aspects, in which people share justice to shoulder their burdens and share their revenues. In terms of the Human Development Index, it has three subdirectories: the Life Expectancy Index, which combines the indices of longevity and health.
The importance of the development strategy in Egypt comes especially in light of the current circumstances and its local, regional and global dimensions, which require reconsideration of the development vision to keep abreast of these developments and develop the best ways to deal with them so as to enable the Egyptian society to rise from its stalemate and move to the ranks of developed countries and achieve the desired development goals. Analytical data of human development 
reports in Egypt vary and development gaps between different governorates, between rural and urban, in addition to the qualitative gap between males and females.

Fayoum Governorate is considered one of the most important governorates in the Republic. The study focuses on the development of human development indicators. The low level of human development reports for the years 2003, 2006 and 2007 requires concerted efforts among development planners, Development studies, in order to accurately identify the potential and determinants of development and appropriate mechanisms to promote development indicators of conservation. At the same time, the interest in most of the world has increased in recent times with NGOs. This concern is mainly due to the expected role it plays as a result of some developments in modern human society, especially its role in development.

\section{Materials and Methods}

\section{The study Problem}

It is clear from the reality of HDR data that there are disparities between the major human development indicators, the disparity between the values and indicators of development between the various regions. This reflects evidence of inequality, which can be inferred from the low level of human development, and identify the most important obstacles and imbalances that determine the future vision aimed to improve the level of human development in general and the impact on the factors leading to the development of the level of health, education and economic for population. In addition to encouraging the contributions of civil society in all its forms of cooperation, private and community participation in the implementation of various developmental activities. Where suggestions can be made to eliminate or reduce the disparity in services to achieve balance between rural and urban areas in society and to eliminate the impact of natural and human factors that stand in the way of achieving comprehensive and balanced development through the use of development efforts for youth and women and civil society organizations and activating the role of small project for its great importance in achieving development.

\section{Objectives of the study}

Analysis of the most important indicators of human development in Fayoum Governorate, Egypt, and evaluation of some developmental projects and services provided by civil society organizations, and their results in achieving higher rates of human development in Fayoum Governorate, Egypt.

\section{Review of Literatures}

A study of EnasSadek 2003, which dealt with an analytical study of the most important indicators of human development in Egypt and the challenges of the future, showed that the results of the study indicate that Egypt is ranked among the countries from 115 to 120 out of 175 countries. Egypt suffers from the low level of Education and the guide to gross domestic product, where the illiteracy rate exceeds $44.7 \%$, and the index of human poverty to about $31.2 \%$ of the total population. Egypt is ranked 91th in terms of performance, 62 out of 140 countries.

In the study of Abdul Tawab 2008, which relates to the economic effects of the activities of some NGOs in Fayoum Governorate, the results showed that the number of NGOs has increased in the last period since 2002. It also became clear that the revenues of NGOs have fluctuated between the increase and the decrease, it had about LE 223.2 million in 1996, with a value of LE 114.5 million in 
1995. A study by Mostafa and EnasSadek 2009, found that there are disparities and developmental gaps between different governorates and rural and urban geographical areas, in addition to the qualitative gap between males and females. Fayoum governorate is considered one of the most important governorates in the Republic. The study also recommends the development of a general strategy for comprehensive development and reconsidering the role of the state in this strategy.

As indicated by the study of Khalifa 2011, the results of the study indicated that the association welcomes the participation of the people in the projects of environmental protection, where the percentage from the point of view of the beneficiaries $81.3 \%$, and also helps community members to interview with officials to find solutions to environmental problems, Implementation and work to remove the difficulties faced by members of the community in the implementation of those projects.

The study of NohaTawfek 2013, which dealt with an economic study of the most important small agricultural projects in Fayoum Governorate, is based on economic analysis of the performance of the most important small agricultural projects. The results indicated that the most important agricultural projects in Fayoum Governorate are livestock, Poultry, municipal and foreign patrons, table eggs, municipal and suburban palaces, outstanding environmental products, fish production projects, olive oil projects, animal and poultry production feed projects.

\section{Data sources}

Fayoum Governorate is located $90 \mathrm{~km}$ away from Cairo Governorate. It is located in the Western Desert in the south-west of Cairo Governorate. The total area of Fayoum
Governorate is $6068 \mathrm{~km} 2$. It has a population of 3.3 million divided into 6 centers. They are Fayoum, Sinnouris, Ibshway, Atsa, Tameh, Youssef Siddiq.

After collecting and reviewing the data, a manual was designed to encode it, and on the basis of the data was manually emptied and then entered into the computer for analysis using the statistical program Spss.

The study used some descriptive and descriptive statistical methods to present and describe the data through the use of some measures and indicators of economic analysis of the economic development projects of the sample of the study, namely:

Total cost, return of the invested pound $=$ total revenue / total costs, profitability of the pound spent per year $=$ net return $/$ cost, the profitability of the pound spent per month $=$ the profitability of the pound spent per year / the number of months of the year of the project.

\section{Results and Discussion}

\section{Features and Indicators of Human Development Index in Fayoum Governorate Compared to the Republic}

Comparing the indicators of human development at the level of Fayoum Governorate with their characteristics at the level of the Republic, the data in Table 1, show the features and indicators of the General Human Development Index in Fayoum governorate, which shows that the general directory of the governorate is about0.584. Which means that Fayoum governorate is located at the low level of development which falls within the level of $0.550-0.599$ According to the Global Human Development Index (HDI), the development gap between human development indicators in 
Fayoum Governorate compared with the same rate in the republic is estimated at $27.2 \%$, $12.2 \%, 3.8 \%$ to $17.9 \% 9 \%, 5 \%$. In terms of the education index, the GDP index, the life expectancy index at birth, the evolution of the human development indicators during the period 2001-2006 compared to 2016 at the governorate level with the same rate at the level of the republic.

\section{Features and Indicators of the Human Development Index Associatedwith Deprivation Index in Fayoum Governorate}

The data in Table 2 show the characteristics and indicators of the deprivation index in Fayoum governorate, which show that the deprivation index was $32.8 \%$ at the governorate level, and the high rate of deprivation in rural areas which reached about $35.8 \% 9 \%$, which is due to the poor services provided to the rural population. It was also found that the index of the age of death before the age of 60 was about $18.4 \%$, the illiteracy rate was about $48.1 \%$ and the percentage of the population below the poverty line was about $36 \%$ Unemployment was about $6.6 \%$, and the gap in the standard of living was $23.3 \%$. The percentage of the population without safe water was about $1.1 \%$, while the percentage of the population without sanitation was and $71.3 \%$. The number of underweight children under the age of five reached $4.3 \%$. The number of children out of primary education reached $16.7 \%$.

It is noted from the previous presentation of the deprivation index in Fayoum governorate, the high rate of deprivation in the governorate, at the level of all the basic areas, which include the standard of living, education, unemployment and health, which corresponds to the classification of Maslow (the theory of humanitarian motives) This indicates that Fayoum is located in the last level in the pyramid Maslow Which represents the physiological and basic needs of the population.

\section{Evaluation of Economic Development Projects Under Study}

\section{Dairy Industry Projects}

The table below shows the distribution of the study sample for the dairy project, where the beneficiaries of this project were about 5 beneficiaries. Table (3) and (4) LE per month), while the rate of return of costs and the profitability of the pound spent per month and the profitability of the pound spent annually amounted to about (137.5\%, 0.031, 0.375 , respectively).

\section{Vegetables and Fruits Trade Project}

The data presented in Table (3) shows the distribution of the sample of the study for the vegetable and fruit trade project. The number of beneficiaries who carried out this project reached about 41 beneficiaries. As shown in table (4), the application of project evaluation criteria that the net return amounted to about (1250 pounds per month) while the rate of return of costs and the profitability of the pound spent per month and the profitability of the pound spent annually amounted to about (165.8\%, 0.054, 0.657, respectively).

\section{Tricycle Project}

The data presented in Table (3) shows the distribution of the sample of the study for the Tricycle project, where the beneficiaries of this project reached about (6) beneficiaries. Table(4) shows that the project evaluation criteria reached about 1850 LE per month, While the rate of return on costs and the profitability of the pound spent per month and the profitability of the pound spent annually amounted to about (158.7\%, 0.587, 0.0489, respectively). 
Table.1 Development of the most important indicators of human development in Fayoum Governorate, Republic of Egypt during the period 2001-2016

\begin{tabular}{|c|c|c|c|c|c|}
\hline $\begin{array}{c}\text { Education } \\
\text { Guide }\end{array}$ & $\begin{array}{c}\text { Life } \\
\text { expectancy } \\
\text { index at birth }\end{array}$ & $\begin{array}{c}\text { Directory of } \\
\text { Gross } \\
\text { Domestic } \\
\text { Product }\end{array}$ & $\begin{array}{l}\text { Average } \\
\text { per capita } \\
\text { GDP }\end{array}$ & \multicolumn{2}{|c|}{ Statement } \\
\hline 0.536 & 0.676 & 0.584 & 3301.8 & $\begin{array}{c}\text { Fayoum } \\
\text { Governorate }\end{array}$ & \multirow[t]{3}{*}{2001} \\
\hline 0.682 & 0.702 & 0.655 & 5060.9 & Republic & \\
\hline 27.24 & 3.85 & 12.16 & 53.28 & $\begin{array}{c}\text { Rate of } \\
\text { change** }\end{array}$ & \\
\hline 0.543 & 0.733 & 0.551 & 2708.5 & $\begin{array}{c}\text { Fayoum } \\
\text { Governorate }\end{array}$ & \multirow[t]{3}{*}{2004} \\
\hline 0.685 & 0.760 & 0.622 & 4151.5 & Republic & \\
\hline 26.15 & 3.68 & 12.88 & 53.28 & $\begin{array}{c}\text { Rate of } \\
\text { change** }\end{array}$ & \\
\hline 0.609 & 0.735 & 0.662 & 5252.9 & $\begin{array}{c}\text { Fayoum } \\
\text { Governorate }\end{array}$ & \multirow[t]{3}{*}{2006} \\
\hline 0.718 & 0.727 & 0.681 & 5899.7 & Republic & \\
\hline 17.9 & 0.05 & 2.9 & 11.7 & $\begin{array}{c}\text { Rate of } \\
\text { change** }\end{array}$ & \\
\hline 13.6 & 8.7 & 13.36 & 60 & $\begin{array}{c}\text { Fayoum } \\
\text { Governorate }\end{array}$ & \multirow[t]{2}{*}{$\begin{array}{c}\text { Rate of } \\
\text { change }{ }^{* * * * *}\end{array}$} \\
\hline 5.3 & 10 & 3.97 & 16.6 & Republic & \\
\hline 0.562 & 0.694 & 0.575 & 3754.4 & $\begin{array}{c}\text { Fayoum } \\
\text { Governorate }\end{array}$ & \multirow[t]{3}{*}{2016} \\
\hline 0.692 & 0.729 & 0.652 & 5037.4 & Republic & \\
\hline 23.7 & 5.4 & 8.6 & 34.17 & $\begin{array}{c}\text { Rate of } \\
\text { change** }\end{array}$ & \\
\hline 2.6 & 1.8 & 2.4 & 38.6 & $\begin{array}{c}\text { Fayoum } \\
\text { Governorate }\end{array}$ & \multirow[t]{2}{*}{$\begin{array}{c}\text { Rate of } \\
\text { change }{ }^{*-* * * * * *}\end{array}$} \\
\hline 1.3 & 2.7 & 3 & 21.4 & Republic & \\
\hline $\begin{array}{l}* * \text { The rate of } \\
* * * \text { Change ra } \\
* * * * \text { Rate of c } \\
\text { Source: Natio } \\
\text { Development }\end{array}$ & $\begin{array}{l}\text { ge and the differ } \\
\text { tween two perio } \\
\text { e between two } p \\
\text { lanning Institute } \\
\text { rt, 2003, 2006, } 2\end{array}$ & $\begin{array}{l}\text { etween the Re } \\
\text { econd period } 2 \\
=\text { (second peri } \\
\text { peration with }\end{array}$ & $\begin{array}{l}\text { and Fayour } \\
\text { first period } \\
16 \text { - first pe } \\
\text { nited Nation }\end{array}$ & $\begin{array}{l}\text { ernorate. } \\
\text { / first period } 200 \\
\text { 06) / first perioc } \\
\text { elopment Progra }\end{array}$ & $\begin{array}{l}00 . \\
6 \times 100 . \\
6 D P\end{array}$ \\
\hline
\end{tabular}


Table.2 Human Development Index related to deprivation index

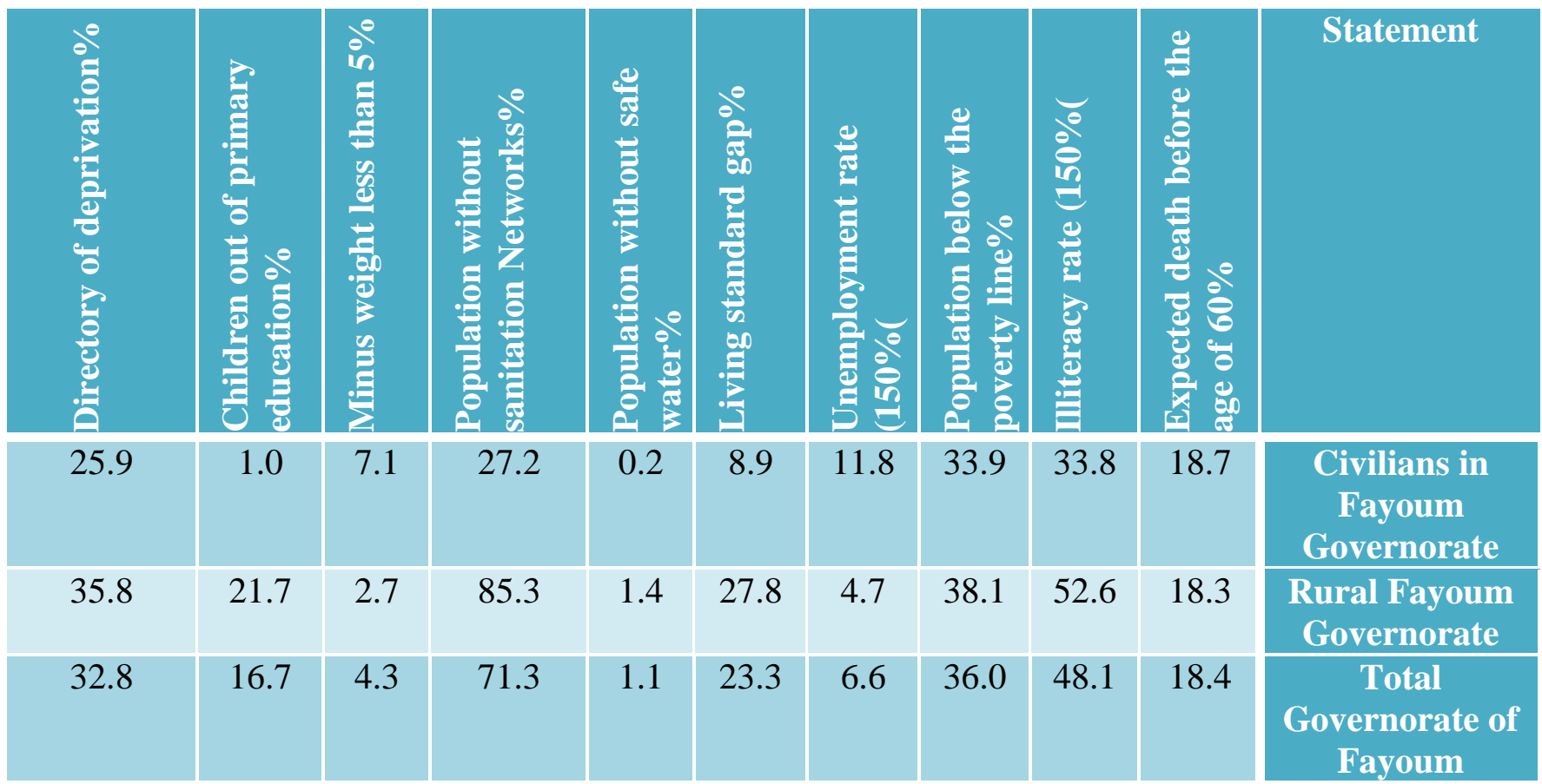

Source: National Planning Institute, Local Human Development Report, Fayoum Governorate, published data, 2016.

Table.3 Frequency, relative distribution, average cost and revenue of economic development projects for beneficiaries of the study of economic development projects in Fayoum Governorate during 2017

\begin{tabular}{|c|c|c|c|c|c|}
\hline $\begin{array}{c}\text { Net } \\
\text { return }\end{array}$ & $\begin{array}{l}\text { Value of } \\
\text { revenue }\end{array}$ & Value of costs & $\%$ & Repetition & Project Type \\
\hline 1850 & 5000 & 3150 & 21.43 & 6 & Tricycle \\
\hline 900 & 3300 & 2400 & 17.85 & 5 & $\begin{array}{l}\text { Manufacture of } \\
\text { dairy products }\end{array}$ \\
\hline 1200 & 2950 & 1750 & 14.28 & 4 & $\begin{array}{c}\text { Detail and } \\
\text { garment trade }\end{array}$ \\
\hline 833 & 2083 & 1250 & 7.14 & 2 & $\begin{array}{l}\text { Agricultural } \\
\text { seedlings }\end{array}$ \\
\hline 670 & 4330 & 3660 & 17.85 & 5 & $\begin{array}{c}\text { Breeding and } \\
\text { trade of poultry } \\
\text { feed }\end{array}$ \\
\hline 1100 & 5600 & 4500 & 7.14 & 2 & $\begin{array}{c}\text { Shops and grocery } \\
\text { store }\end{array}$ \\
\hline 1250 & 3150 & 1900 & 10.72 & 3 & $\begin{array}{c}\text { Vegetables and } \\
\text { fruits } \\
\end{array}$ \\
\hline 700 & 1500 & 800 & 3.57 & 1 & Compost \\
\hline- & - & - & 100 & 28 & Total \\
\hline
\end{tabular}

Source: Compiled and calculated from beneficiary questionnaire form data. 
Table.4 Indicators of the evaluation of the operation of economic development projects for beneficiaries in Fayoum Governorate during the year 2017

\begin{tabular}{|c|c|c|c|c|}
$\begin{array}{c}\text { The } \\
\text { profitability of } \\
\text { pound spent } \\
\text { annually }\end{array}$ & $\begin{array}{c}\text { The } \\
\text { profitability of } \\
\text { pound is spent } \\
\text { monthly }\end{array}$ & $\begin{array}{c}\text { Rate of } \\
\text { return to } \\
\text { cost } \%\end{array}$ & $\begin{array}{c}\text { The yield on the } \\
\text { invested pound }\end{array}$ & \begin{tabular}{c} 
Project Type \\
\hline 0.587
\end{tabular} \\
\hline 0.0489 & 158.7 & 1.587 & Tricycle \\
\hline 0.375 & 0.031 & 137.5 & 1.375 & Manufacture of dairy \\
\hline 0.168 & 0.014 & 168.5 & 1.685 & Detail and garment trade \\
\hline 0.666 & 0.055 & 166.6 & 1.666 & Agricultural seedlings \\
\hline 0.183 & 0.015 & 118.3 & 1.183 & Breeding and trade of \\
\hline 0.244 & 0.020 & 124.4 & 1.244 & Shoultry feed \\
\hline 0.657 & 0.054 & 165.8 & 1.657 & Vegetables and fruits \\
\hline 0.875 & 0.0729 & 187.5 & 1.875 & Compost \\
\hline
\end{tabular}

Source: Compiled and calculated from beneficiary questionnaire form data.

\section{A commercial and Grocery Project}

Table (3) shows the distribution of the sample of the study for a commercial and grocery project where the beneficiaries of this project were about (2) beneficiaries. as shown in table (4), the application of the criteria for evaluating the projects that the net return amounted to about (1100 pounds per month) while the rate of return on costs and the profitability of the pound spent per month and the profitability of the pound spent annually amounted to $(124.4 \%, 0.020,0.244$, respectively).

\section{Project Detail and Clothing Trade}

The data presented in Table (3) shows the distribution of the sample of the study for the project of clothing detail and trade. The number of beneficiaries who carried out this project reached about 4 beneficiaries. Table (4) shows that the economic analysis showed that the net return was about 1200 LE per month.while the rate of return on costs and profitability of the pound spent per month and the profitability of the pound spent annually amounted to about $(168.5 \%, 0.014,0.168$, respectively).

\section{Breeding and Trading Poultry Feed Project}

The data presented in Table (3) shows the distribution of the sample of the study for the poultry feed breeding and trade project. The number of beneficiaries who carried out this project reached about 5 beneficiaries, as shown in table (4) by applying project evaluation criteria, the net return was about LE 670 per month. While the rate of return on costs and profitability of the pound spent per month and the profitability of the pound spent annually amounted to $(118.3 \%, 0.015,0.183$, respectively).

\section{Project of Compost Production}

The data in table (3) show the distribution of the sample of the study for the compost production project, where the beneficiaries of this project reached about (1) beneficial as shown in table (4), the application of the project evaluation criteria that the net return 
amounted to (700 pounds per month), while the rate of return for costs and the profitability of the pound spent per month and the profitability of the pound spent annually amounted to $(187.5 \%, 0.875,0.0729$, respectively).

\section{Production and Sale of Seedlings Project}

The data presented in Table (3) show the distribution of the sample of the study for the poultry feed breeding and trade project, where the beneficiaries of this project were about 2 beneficiaries. as shown in table (4), the application of the project evaluation criteria that the net return amounted to about (670 pounds per month), while the rate of return on costs and the profitability of the pound spent per month and the profitability of the pound spent annually amounted to $166 \%, 0.666$ and 0.055 respectively. Table 4 shows that the most important projects according to the net return Triscl, while it was clear from the previous description that the most important projects in terms of economic analysis is the compost project.

\section{References}

Abdel Tawab, M. O. (2006). Economic Effects of Activities of Some NonGovernmental Organizations in Fayoum Governorate, Master Thesis, Department of Agricultural Economics,
Faculty of Agriculture, Fayoum University.

Khalifa, O.A. (2011). The Contributions of Civil Society Organizations to Mitigating Environmental Problems Facing Sustainable Development, Master Thesis, Department of Development and Planning, Faculty of Social Work, Fayoum University.

Mostafa, A.M., Sadek, E. (2009). An Analytical Study of Indicators of Human Development and the Possibilities for Improving the Standard of Living in Fayoum Governorate, Egyptian Journal of Agricultural Economics, Volume 19, No, 4.

National Planning Institute in cooperation with the United Nations Development Program (UNDP), Human Development Report, 2003, 2006, 2007.

National Planning Institute, Local Human Development Report, Fayoum Governorate, published data, 2016.

Tawfek, N. (2011). Economic Study of the most important Small Agricultural Projects in Fayoum Governorate, Ph.D. Thesis, Department of Agricultural Economics, Faculty of Agriculture, Fayoum University.

Tolba, A., Sadek, E. (2003). An Analytical Study of the Most Important Indicators of Human Development in Egypt and Future Challenges, 11th Conference of Agricultural Economists (Human Development in the Rural Sector).

\section{How to cite this article:}

Enas El Sayed Sadek, Osama Metwaly Mohamed and Ghada Abd El Samee Rabee Mansour Ghedan. 2018. Economic Evaluation of Some Projects Funded by NGOs and Their Role in Human Development in Fayoum Governorate, Egypt. Int.J.Curr.Microbiol.App.Sci. 7(06): 2008-2015. doi: https://doi.org/10.20546/ijcmas.2018.706.237 